\title{
The Effectiveness of STEAM-Based Biotechnology Module Equipped with Flash Animation for Biology Learning in High School
}

\author{
Anjar Putro Utomo \\ M.Ed., University of Jember, Indonesia, anjar_pu.fkip@unej.ac.id \\ Luthfiyatul Hasanah \\ S.Pd., University of Jember, Indonesia, luthfiyatul0912@gmail.com \\ Slamet Hariyadi \\ Dr., University of Jember, Indonesia, s.hariyadi.fkip@unej.ac.id \\ Erlia Narulita \\ Dr., University of Jember, Indonesia, 68121.erlia.fkip@unej.ac.id \\ Suratno \\ Prof. Dr., University of Jember, Indonesia, suratno.fkip@unej.ac.id \\ Nurul Umamah \\ Dr., University of Jember, Indonesia, nurul.umamah.fkip@unej.ac.id
}

\begin{abstract}
This study aims to determine the effectiveness of the STEAM (Science, Technology, Engineering, Arts, and Mathematics)-based biotechnology module equipped with flash animation for learning biology in high school. This research was conducted in a high school, involving 32 students of Year XII. The research design was the design model for development of R2D2 with one group pretestposttest design as effectiveness tests. This study utilized a learning design, biotechnology modules equipped with flash animation, instrument testing, validation sheet and questionnaire as research instruments. Data validation and the questionnaire results were then converted into qualitative data into a category. The effectiveness test data were analyzed using the $\mathrm{N}$ gain. The results of the validation material, media and users indicated that the module was valid with the final score of 89.85. Students' responses to the module in terms of readability, clarity of presentation, the attractiveness and usefulness of the results were in very good category $(81.2 \%)$. The effectiveness test showed that result of post-test greater than pre-test and the value of $\mathrm{N}$ gain were in the high category $(0.72)$.
\end{abstract}

Keywords: effectiveness, STEAM, modules, biotechnology, learning

Citation: Utomo, A. P., Hasanah, L., Hariyadi, S., Narulita, E., Suratno, \& Umamah (2020). The Effectiveness of STEAM-Based Biotechnology Module Equipped with Flash Animation for Biology Learning in High School. International Journal of Instruction, 13(2), 463-476. https://doi.org/10.29333/iji.2020.13232a 


\section{INTRODUCTION}

$21^{\text {st }}$-century learning requires human to possess information management and technologies skills, to learn and innovate, to pursue their career and to gain global consciousness, as well as good character. To meet the high market demand for science and technology based products requires educational system that is able to answer the challenge. One approach with the potential to answer the demands of $21^{\text {st }}$-century learning is STEAM (Science, Technology, Engineering, Arts, and Mathematics) based learning. STEAM-based learning is a learning system developed in Korea which is an adoption of STEM learning systems in the USA (Baek et al., 2011; Yakman, 2008). STEAM learning system has been a popular topic of discussion in Korea and is expected to address the rapid global changes (Daker, 2006). This approach encourages students to be problem solvers with integrated thinking, which in turn will make students to be able to compete in the new knowledge-based economy (Lee, 2003).

The STEAM approach involves reflective integration of science into technology and into engineering and art, all of which contain the elements of mathematics as the master of science (Yakman, 2008). One of the elements of science adheres to Biology. Biological material which can be integrated into STEAM approach is Biotechnology. Biotechnology includes the application of the principles of biological science and technology in everyday life. Biotechnology as a science is very complex, multidimensional, very scientific, technological, sociological and is strongly related to ethics (Moreland et al., 2006). Biotechnology is also a multidisciplinary science that is more applicative in nature; hence, it requires the mastery of the correct basic concepts, and it is also developing very rapidly because of its benefit to improve human living standards (Sohan et al., 2003). In its application, it is crucial to concern aspects of science and technology, as well as how to apply it through engineering/design process.

Biotechnology learning problems are closely related to the teaching materials used during lessons (Utomo et al., 2017). One teaching material to train students' independence is a module. Module is compiled systematically which includes content, methods, and the evaluation tool developed (Basilotta, 2017). Biotechnology material contains abstract sub-materials of genetic engineering which can be difficult for students to understand (Venville, 2002). Printed media may not be able to explain the abstract processes in the genetic engineering, but the electronic media such as flash animation may be able to cover the shortage. In this study, STEAM-based biotechnology module is equipped with a flash animation as a form of development of the printed media into semi-electronic media, which mas help visualize the abstract sub-materials. $80 \%$ of teachers stated that they had used a module but it fails to show interconnection between science, technology, mathematics and art that can help improve student learning outcomes (Febriyanti, 2018). Therefore, the development of Biotechnology module based STEAM approach presents activities that need to be implemented by students through the application of science concept in everyday life context by integrating Technology, Engineering, Art, and Mathematics concept and skills in order to solve the actual problem of conventional Biotechnology. This module is equipped by flash animation that makes it easier for students to understand the abstract content on modern 
Biotechnology. There has been no other studies conducted on this matter. Other studies applied book or module based on STEAM approach without flash animation or other electronic media additions. Approaches, materials and instructional media used by learners can be considered good if it can help achieve the learning objectives measured by the effectiveness of learning (Sudjana, 1990). Therefore, it is necessary to examine the effectiveness of STEAM-based biotechnology module.

\section{LITERATURE REVIEW}

\section{STEAM Approach}

STEAM is originated from STEM which was introduced by the NSF (National Science Foundation) of United States in the 1990s as an abbreviation for "Science, Technology, Engineering, and Mathematics" (Sanders, 2009); with addition of artistic element (Yakman, 2008). Torlakson (2014) states that the approach is a perfect match between the problems that occur in the real world and the problem-based learning. Component $\mathrm{A}$ (art) is an important part to be added in STEM because art is a part of the intertwining elements of STEM. Art includes aesthetics, ergonomics, sociology, psychology, philosophy, and education (Yakman et al., 2012). This approach is able to create a cohesive learning system and active learning for all four aspects simultaneously required to solve a problem.

STEAM may be applicable in the various types and levels of learning environment. Therefore, STEAM can accurately be a proxy of the surrounding culture and developed to be tolerant to all types of diversity. Thus all students can learn about the culture surrounding it, and the surrounding culture can be the media of learning for them (Lee, 2012). In conclusion, STEAM education requires a context as a medium to foster the integration of Science, Technology, Engineering, Art and Mathematics disciplines and provides a wide range of treatments in development. This fact is supported by Lee (2012) that a context can mediate STEAM.

The most well-known context or phenomenon in this respect in all areas, even across countries and regions is the local knowledge, particularly the local culture. Sophisticated science and technology are created due to cultural degradation (Mungmachon, 2012), then the degradation of moral and socio-cultural values takes place in local communities/cultures. Local knowledge can reinforce the contextual learning that can stimulate and improve the ability to think critically and creatively and to encourage every student in the school to be discreet and wise in resolving life problems (Santrock, 2011).

The description of the local knowledge above can include Art and the proper context in STEAM-based learning module (Utomo, 2017). Art in STEAM and local knowledge has a value that can instill the skills to think critically and creatively to solve problems for students. Thus, the context of local knowledge related to biotechnology will maximize the role of STEAM approach to the learning process as outlined in a learning module. 
As for the 5 traits of STEAM based on the definition set out by Torlakson (2014), namely: (1) science that represents knowledge of the laws and concepts that apply in nature; (2) technology as a skill, or a system used in governing society, organization, knowledge or design as well as using a tool made to facilitate the work; (3) Engineering as knowledge to operate or design a procedure to solve a problem; and (4) Art which includes aesthetics, ergonomics, sociology, psychology, philosophy, and education. To be more specific art can be a language of art, the art of movement/physical, social art and fine art (5) Mathematics as the science that connects the scale, numbers and spaces that require only a logical argument without or accompanied by empirical evidence. This can make all aspects of knowledge become more meaningful when it is integrated into the learning process (Ariningtyas et al., 2017).

\section{Biotechnology Module and Flash Animation}

Learning media has the following practical values: First, media can overcome problems with students' limited experience. Second, media can overcome the limitations of the classroom. Media in this regard is mainly utilized to present learning materials that are too difficult for students to understand straightforwardly. One example of the learning media is a module which can help improve the quality of students' education.

The implementation of the module with the STEAM approach (Science, Technology, Engineering, Art, and Mathematics) in biology learning, especially biotechnology material is expected to improve the effectiveness of learning. It is expected to make classroom learning more feasible, practical, and effective. Through the implementation of the module with STEAM (Science, Technology, Engineering, Art, and Mathematics) approach in learning Biotechnology, students are invited to learn to be independent and be able to solve a problem themselves.

Flash is one of the products of Macromedia/Adobe which can be categorized as highly reliable, proven by the wide use of flash-based animations. Besides the ease to create animations, flash also provides complete supporting features, making the animations created more attractive. Animation is a star-shaped images of a set of objects (images) arranged in an orderly manner following the flow of motion along a timeline. The definitions of images or object referred to above may include images of humans, animals, or letters. Flash animation based learning media is able to motivate student learning and to construct new knowledge through the senses of sight and hearing (Veselinovska, 2015). In addition, the multiple functions of flash-based animation audiovisual instructional media, as stated Levie and Lentz (1982) are four folds, especially visual media, namely: a) attention function, b) effective function, c) cognitive function, d) competence function. Dale (1969) suggests that audio-visual equipment can provide many benefits as long as teachers play an active role in the learning process.

Biotechnology is one of the fastest growing sciences today which plays a crucial role in the rapid progress in various fields of life. Biotechnology is not only one of the relatively complicated disciplines, but also a science that develops highly complex and contentious in various areas such as ethics, politics, and morals. Despite being considered a complicated branch of science, biotechnology relates strongly with the 
improvement of human well-being; therefore, it is essential to master this science (Moreland et al., 2006).

\section{Learning Outcomes}

Learning outcomes are statements showing what learners are expected to know, understand or be able to show at the end of the study period (Steiner \& Morberg, 2006). Broadly speaking, learning outcomes are divided into three of Bloom's taxonomy domains, namely cognitive, affective, and psychomotor skills. Learning is essentially aimed to gradually improve learners' cognitive, affective, and psychomotor skills (Gagne, 1965). These capabilities were developed with a variety of innovative and creative instructional strategies. Learning is an activity between educators and learners as a result of changes in behavior for learning experiences to achieve the learning objectives (Ambrose et al., 2010). Teachers can use the learning modules that correspond to the needs of learners. The right module for learning is appropriate to the needs of learners in the days of the digital era is module-based learning of Science, Technology, Engineering, Arts and Math (STEAM) which is intended to support the possibility for students to learn anywhere and anytime.

Learning associated with aspects of STEAM will help learners to collect and analyze and solve problems that occur and be able to understand the relationship between one problem and another (Duschl, 2011). STEAM-based education forms human resources (HR) that are able to reason and think critically, logically, and systematically, so that they will be able to face global challenges and be able to improve the country's economy.

\section{METHOD}

\section{Research Design and Participants}

The research design used was one group pretest-posttest design. The study was conducted at Class XII second semester of the academic year 2018/2019. The number of participants in this study was 32 students. The material presented was Biotechnology. Before testing the effectiveness of the module, validation was firstly done. The validation was conducted by 5 expert validators. Two experts assessed the feasibility of material content, presentation and linguistic. two media experts and developers assessed the feasibility of module graphics and flash animation as well as the development of learning media. One validator was a user that was a biology teacher who assessed the feasibility of the content, presentation, linguistic, modules graphics and animation when applied during the class learning. When the said validator declared that the module was valid, the effectiveness test was then performed.

Steps taken in the effectiveness test were: at the beginning of the meeting the students mastery on biotechnology was assessed in the pre-test (first test) $\mathrm{O} 1$ and followed by learning using the STEAM-based module (Science, Technology, Engineering, Arts, and Mathematics) equipped with flash animation (treatment), and the end of the study students' mastery of biotechnology materials was again assessed in the post-test (final test) $\mathrm{O} 2$. In this research, only one sample group served as a control group (before 
treatment) and the experimental group (after treatment). This design was used to compare the progress of students after learning by using STEAM-based biotechnology module equipped with flash animation to before using the module. Efficacy data in this study was obtained through the test instrument, in the form of questions addressed to students and coupled with the data in the form of a questionnaire response of students about modules that were used during the learning. Questionnaires were given to students containing 30 questions about readability, clarity of presentation (material, pictures, and animations), the attractiveness and usability/usefulness.

\section{Data Analysis}

Validation results were analyzed using percentage techniques (Utomo et al., 2014; Wahono et al., 2018), which were then converted into quantitative data with the criteria in Table 1. If the validation results reached $59.26 \%$, the product was declared valid and would be continued with the effectiveness test. While the readability and difficulty test data were analyzed descriptively by reviewing the results of student responses. Student questionnaire responses were used to measure students' opinions about the modules used during learning. The percentage of student responses was calculated using the following formula and the criteria can be seen in Table 2:

$V=\frac{T_{g e}}{T_{g m}} \times 100 \%$

$\mathrm{V}=$ number of assessment scores

$T S E=$ number of empirical scores

$T S M=$ maximum score

Table 1

Validity Criteria

\begin{tabular}{ll}
\hline Interval Score & Category \\
\hline $19.00 \leq \mathrm{Va}<39.25$ & Invalid \\
$39.26 \leq \mathrm{Va}<59.25$ & Less Valid \\
$59.26 \leq \mathrm{Va}<79.25$ & Valid \\
$79.26 \leq \mathrm{Va} \leq 100$ & Very valid \\
\hline
\end{tabular}

Table 2

Student Response Criteria

\begin{tabular}{ll}
\hline Percentage of Student Response & Student Response Criteria \\
\hline $20 \leq X<32$ & Not Very Good \\
$32 \leq X<44$ & Not Good \\
$44 \leq X<56$ & Good Enough \\
$56 \leq X<68$ & Good \\
$68 \leq X \leq 100$ & Very Good \\
\hline
\end{tabular}

Analysis of activity data from tests on the effectiveness of the activities was carried out by using descriptive qualitative approach. The data were analyzed by the N-gain. The data were obtained by analyzing the scores of pre-test and post-test students, then calculate the index gain. The results of gain indexes were converted into quantitative 
data with the criteria in Table 3 . The gain index was calculated using the gain index formula according to Hake (1998: 66), namely:

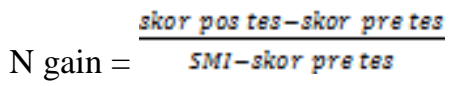

Description: SMI = Ideal Maximum Score

Table 3

Score Gain Criteria

\begin{tabular}{ll}
\hline Gain score & Criteria \\
\hline $\mathrm{G}<0.3$ & Low \\
$0.3 \leq \mathrm{g}<0.7$ & Medium \\
$\mathrm{G} \geq 0.7$ & High \\
\hline
\end{tabular}

STEAM-based biotechnology module equipped with flash animation was said to be effective if the learning outcomes of students increased by an average score of $\mathrm{N}$-gain of $0.3 \leq \mathrm{g}<0.7$ in the medium category. While learning can be said to be successful if individual student learning outcomes reached $65 \%$ and were considered successful in classical learning if learning outcomes of students reached $\geq 85 \%$ (Meltzer, 2002).

\section{FINDINGS}

The results of the assessment by five validators on the biotechnology module equipped with flash animation are presented on Table 4 and the results of the student response questionnaire are on Table 5.

Table 4

The Results of the Validation of the STEAM-Based Biotechnology Module Equipped with Flash Animation

\begin{tabular}{|c|c|c|c|c|c|c|}
\hline \multirow[t]{2}{*}{ No } & \multirow[t]{2}{*}{ Expert Validator } & \multirow[t]{2}{*}{ Aspect } & \multicolumn{2}{|l|}{ Score } & \multirow{2}{*}{$\begin{array}{l}\text { Average } \\
\text { score }\end{array}$} & \multirow[t]{2}{*}{ Category } \\
\hline & & & 1 & 2 & & \\
\hline \multirow[t]{3}{*}{1} & Material & Feasibility of Contents & 92.5 & 75 & 83.75 & Very valid \\
\hline & & Feasibility of Presentation & 92.31 & 92.31 & 92.31 & Very valid \\
\hline & & Linguistics & 90.90 & 93.18 & 92.04 & Very valid \\
\hline \multicolumn{5}{|c|}{ The Mean Results of Material Validation } & 89.37 & Very valid \\
\hline \multirow[t]{3}{*}{2} & $\begin{array}{l}\text { Media and } \\
\text { Developers }\end{array}$ & $\begin{array}{l}\text { Feasibility of Graphic } \\
\text { Integrity }\end{array}$ & 89 & 93 & 91 & Very valid \\
\hline & & $\begin{array}{l}\text { Feasibility of Flash } \\
\text { Animation }\end{array}$ & 87.5 & 75 & 81.25 & Valid \\
\hline & & Media Development & 91.6 & 91.6 & 91.60 & Very valid \\
\hline \multicolumn{5}{|c|}{ The Mean Results of Media Validation } & 87.95 & Very valid \\
\hline \multirow[t]{5}{*}{3} & User & Feasibility of Contents & 96.25 & - & 96.25 & Very valid \\
\hline & & Feasibility of Presentation & 94.23 & - & 94.23 & Very valid \\
\hline & & Linguistics & 90.40 & - & 90.40 & Very valid \\
\hline & & $\begin{array}{l}\text { Feasibility of Graphical } \\
\text { Module }\end{array}$ & 90.27 & - & 90.27 & Very valid \\
\hline & & $\begin{array}{l}\text { Feasibility of Flash } \\
\text { Animation }\end{array}$ & 90 & - & 90 & Very valid \\
\hline \multicolumn{5}{|c|}{ The Mean User Validation Result } & 92.23 & Very valid \\
\hline \multicolumn{5}{|c|}{ The Mean Experts Validation Result } & 89.85 & Very valid \\
\hline
\end{tabular}


Based on the results of the validation of data obtained from the mean score of two material expert validators were 89.37. A result of the mean score of two validators of media expert and developer was 87.95. The scores of users were 92.23. The results of the five expert validators were then averaged so that the results of the validation of the STEAM-based biotechnology module equipped flash animations of 89.85 with very valid categories for use in the class learning (Table 4). The validation result is not strikingly different with the study result (implementation of Biotechnology book based on STEM approach) of Wahono (2018) which was on 86.40 as well as validation result of Biotechnology book based on STEAM-LW was 87.50.

Table 5

Results of the Student Questionnaire Responses on STEAM-Based Biotechnology Modules Equipped by Flash Animation

\begin{tabular}{lll}
\hline Aspect & Percentage (\%) & Category \\
\hline Readability & $81.4 \%$ & Very good \\
Clarity of Presentation (material, pictures, animation) & $82.6 \%$ & Very good \\
Attractiveness & $80.4 \%$ & Very good \\
Usability/Usefulness & $80.3 \%$ & Very good \\
Average & $81.2 \%$ & Very good \\
\hline
\end{tabular}

Table 5 shows that the results of students' responses to the aspect of legibility was excellent with a percentage of $81.4 \%$, to clarity (material, images, animation) was very good with a percentage of $82.6 \%$, attractiveness was also very good with a percentage of $80.4 \%$, usability / usefulness was very good with a percentage of $80.3 \%$. The final result obtained from the average of students' responses to STEAM-based biotechnology equipped flash animation was equal to $81.2 \%$ and in the excellent category. These results show that the modules were read properly with clear presentations of materials, images, and animation, were interesting, and had assisted students to improve learning.

Table 6

The Mean Results of N-Gain Test

\begin{tabular}{lllll}
\hline Aspect & $\begin{array}{l}\text { Average pre-test } \\
\text { Value }\end{array}$ & $\begin{array}{l}\text { Average post- } \\
\text { test Value }\end{array}$ & N-gain & N-gain Category \\
\hline Cognitive & 27.51 & 80.09 & 0.72 & High \\
\hline
\end{tabular}

The results of data analysis show that there was a significant increase in the score of students' pretest-posttest. However, if this study used paired sample t-test, the result was in sig. $0.000<0.05$, which means that there is a significant different between Biotechnology learning result on pretest and posttest. It can be seen from the pretestposttest mean value of 32 students. Before students used STEAM-based biotechnology equipped with flash animation, they achieved an average score of pretest of 27.51, after getting treatment; the mean score of student posttest was 80.09 . The effectiveness test results showed that the average score of posttest (80.09)> pretest mean score (27.51). The N-Gain mean result was included in the high category (0.72) (Table 6). Based on the calculation of N-Gain, 53\% of students were included in the high category, $47 \%$ of students were included in the medium category and no student was included in the low category. The effectiveness result shows that there is an improvement of learning result 
on Biotechnology content after using Biotechnology module based on STEM approach with flash animation is in line with the study result of Wahono (2018) which is on n-gain 0.77 .

\section{DISCUSSION}

The results of effectiveness tests carried out on STEAM-based biotechnology module equipped with flash animation are in line with the results of Lee, (2003) and Utomo, et al. (2017) that this approach helped students become problem solvers with integrated thinking, thinking by considering different perspectives stimulates students to become problem solvers with regard to their culture. This means that students will better understand the issues involved (Aldemir \& Kermani, 2016) worked collaboratively to face any challenge of daily life in the future. The learning activities contained in the STEAM-based biotechnology module with the element of "arts" ease the integration with other elements, as in Yakman's statement (2012) that the subject of "arts" in STEAM can provide linkage between subject disciplines, make learning more fun and make learning more realistic with life faced by the students. STEAM education teaches and educates students to work together and respects individual role in the group.

The effectiveness of STEAM-based biotechnology modules equipped with flash animation will train students to develop cognitive, psychomotor, and affective skills in life. This STEAM-based biotechnology module encourages students to understand the concept of biotechnology material through group discussions and practical activities that contain elements of technology, engineering, art, and mathematics. Hence, the STEAM approach presented in the biotechnology module was successful in achieving the learning objectives mainly aims to make students become problem solvers, inventors, independent, logical thinkers, technology literate, and able to connect STEAM to the world of work (Morrison, 2006).

Strengthening the understanding given by elements of technology and engineering. These elements are presented in the form of pilot activities to make tools or objects that can simplify the work of humans, for example one section in the module presents the process to design and build a fermentation media to make nata de coco, fermented soybeans, and simulation to manufacture plant tissue culture media. The design process enhanced the students' ability to understand the concepts and principles of direct labor (Farmer et al .2012; Householder and Hailey, 2012). The presentation of problems in the module also trained students to find answers to the problem through an analysis of what is known and what needs to be completed or corrected (Greenwald, 2000). STEM approach can be integrated into the design of engineering process as a guide for students to master STEM related content (Hmelo, et al., 2000; Mehalik, et al., 2008; Schunn, 2009). This mechanism encourages students to make connections, to help bridge the failure of the design or the next step in the process of engineering and engineering in real life (Lottero-Perdue, 2015). Also, the emphasis on E for Engineering, encouraged the students not only to work cooperatively to develop problem solving and decision making skills but also to think critically and creatively to demonstrate an actual understanding of concepts during science lessons (Wahono, 2018). Therefore, the students learn scientific concepts and their application in engineering and technology, as 
well as the relationships and its application in daily life or a real-world context. The implementation of daily life context in learning can be saved in long-term memory of students, consequently the implementation of science through technology and engineering in STEAM approach can be effective to improve students' learning outcome (Al-Balushi, 2018).

It is impossible to learn technology and engineering without learning science/natural science, and natural science cannot be fully understood without a fundamental understanding of mathematics. Mathematics is not only the primal language but also a practical and theoretical liaison of various learning methods applied including projects, construction, analysis and work processes (Yakman \& Lee, 2012). The method in solving the problems will use the concepts in mathematics, in the form of calculation, measurement, and comparison (Taylor, 2017).

The arts element in the STEAM approach presented in the module is an element that unites STEM, namely the element of creativity. This element becomes a unifier because, in science, technology, engineering, and mathematics, it will be more meaningful and more enjoyable to learn with creativity (Yakman \& Lee, 2012). The creativity element will help in making a concept to achieve goals or to overcome problems, even now researchers hire fiction writers as creative thinkers to help imagine and explain the process of traveling to the moon (Taylor, 2017). In addition, the art element will make the learning atmosphere more interesting and fun for students, in accordance with the results of student responses to the module (see Table 5). According to Eisner (2008) that an open mind, the emergence of emotional awareness and stimulation of imagination caused by arts elements are able to generate expressive, emotional and empathetic understanding so it will facilitate students to achieve learning objectives and improve their learning outcomes. Besides, the artistic element in learning may either improve cognitive or develop social awareness, which is strengthened by Akhmetshin (2018) study by integrating physical activity, art, and culture that affect to the development of cooperate and collaborate attitude of students.

The existence of flash animation in STEAM-based biotechnology module can improve students' learning outcomes for presenting animation on modern biotechnology materials that cannot be practiced and seen directly by students. Through the video content in the form of flash animation students will understand the materials more easily because of the audio-visual elements (O'Day \& Liu, 2007; Supriyati, 2011; Veselinovska, 2015; Zanin, 2015). Visual learning media proposed by Levie and Lentz (1982) has four functions, namely: a) the attention function, b) the affective function, c) the cognitive function, d) the competent function, so that the presence of material in the form of visual animation is more effective than traditional teaching methods in improving students' achievement (Creative education, 2012). The use of technology for present an animation of science content is able to boost student's motivation to do scientific literacy through animated video observation. This activity can stimulate brain work in order to understand a concept casually. Accordingly, it will make student understand the concept of science learning with ease and comfort (Pramuda, 2019). Therefore, the integration of the STEAM element, which is the basis for modules 
development, and the existence of flash animations in modules can improve studentlearning outcomes.

\section{CONCLUSION}

The STEAM-based biotechnology module equipped with flash animation was valid and effective to be used in biology learning in high school. It can be seen from the validity score of 89.85 , the final percentage of student responses to the module of $81.2 \%$, the average score of posttest (80.09) $>$ the average pretest score of (27.51) and the average $\mathrm{N}-$ Gain which was classified into the high category (0.72). This study can give a basic concept for the other researchers who want to focus on development of book or module based on STEAM approach for giving more attention on art aspect as well as engineering design process activities in order to stimulate the development of creativity sense and skills of students.

\section{REFERENCES}

Akhmetshin, E. M., Miftakhov, A. F., Murtazina, D. A., Sofronov, R. P., Solovieva, N. M., \& Blinov, V. A. (2019). Effectiveness of using football basics in physical education and organizing arts and cultural events for promoting harmonious development of orphan children. International Journal of Instruction, 12(1), 539-554. https://doi.org/10.29333/iji.2019.12135a.

Al-Balushi, K. A., \& Al-Balushi, S. M. (2018). Effectiveness of brain-based learning for grade eight students' direct and postponed retention in science. International Journal of Instruction, 11(3), 525-538. https://doi.org/10.12973/iji.2018.11336a.

Aldemir, J., \& Kermani, H. (2016). Integrated STEM curriculum: Improving educational outcomes for head start children. Early Child Development and Care, 1-13.

Ambrose, S., Bridges, M. W., Lovett, M. C., DiPietro, M., \& Norman, M. K. (2010). How learning works: seven research-based principles for smart teaching. Jossey-Bass.

Ariningtyas, A., Wardani, S., \& Mahatmanti, W. (2017). Effectiveness of student worksheets contained with salt hydrolysis material ethnosis to improve science literacy of high school students. Journal of Innovative Science Education, 6(2), 186-196.

Baek, Y., Park, H., Kim, Y., Noh, S., Park, J. Y., Lee, J., Jeong, J. S., Choi, Y., \& Han, H. (2011). Steam education in Korea. Journal of Learner-Centered Curriculum and Instruction, 11(4), 149-171.

Basilotta, G. V., Martín, P. M., \& García, V. M. R. A. (2017). Project-based learning (PBL) through the incorporation of digital technologies: An evaluation based on the experience of serving teachers. Computers in Human Behavior, 68, S40.

Creative Education. (2012). The effects of animation technique on the 7th grade science and technology course Gokhan Aksoy ministry of national education, IMKB primary school, Erzurum, Turkey. Published Online June 2012 in SciRes, 3(3), 304-308. Retrieved 10 May 2019 from http://www.SciRP.org/journal/ce. 
Daker, J. R. (2006). Toward a philosophy for technology education, defining technological literacy: Towards an epistemological framework, New York: Palgrave Macmillan.

Dale, E. (1969). Audiovisual methods in teaching. New York: The Dryden Press

Duschl, R. (2011). Successful STEM education: A workshop summary. Chapter: 3 practice that support effective STEM education.

Farmer, C., Allen, D. T., Berland, L. K., Crawford, R. H., \& Guerra, L. (2012). Engineer your world: An innovative approach to developing a high school engineering design course. Paper Presented at the Meeting of the American Society for Engineering Education, San Antonio, TX.

Febriyanti, E., Indrawati, Supeno, Sutarto, \& Mahardika, I. K. (2018). The effectiveness of the module-based STEM to study physics at vocational high school. Int.J Adv. Res. 6(5), 1367-1370.

Gagne, R. M. (1985). The conditions of learning and theory of instruction. New York: CBS College.

Greenwald, N. L. (2000). Learning from problems. The Science Teacher, 67(4), 28-32

Hake, R. R. (1998). Analyzing changes gain score. Indiana University, USA. Retrieved from http://www.physics.indiana.edu/ sdi/AnalyzingChange-Gain.pdf.

Hmelo, C.E., Holton, D. L., \& Kolodner, J. L. (2000). Designing to learn about complex systems. Journal of the Learning Sciences, 9(3), 247-298.

Householder, D. L., \& Hailey, C. E. (2012). Incorporating engineering design challenges into STEM courses. Retrieved from http://ncete.org/flash/pdfs/NCETECaucusReport.pdf.

Lee, G.Y. (2003). Exploring the exemplary STEAM education in the U.S as practical education framework for Korea. STEAM Education, 1072-1082.

Levie, W. H., \& Lentz, R. (1982). Effects of text illustrations: A review of research. Educational Communication and Technology Journal, 30, 195- 232.

Lottero-Perdue, P. S. (2015). Running head: The engineering design process, responses to failure. Presented at NARST, Towson University.

Mehalik, M., Doppelt, Y., \& Schunn, C. (2008). Middle-school science through designbased learning versus scripted inquiry: better overall science concept learning and equity gap reduction. Journal of Engineering Education, 97(1), 71-85.

Meltzer, D. E. (2002). The relationship between mathematics preparation and conceptual learning gains in physics: A possible-hidden variablell in diagnostic pretest scores. Journal of am J. Phys, 70(12), 160. 
Moreland, J., Jones, \& Cowie. (2006). Developing pedagogical content knowledge for the new sciences: the example of biotechnology. Teacher Education Journal, 17(2), 143-155.

Morrison, J. (2006). TIES STEM education monograph series: Attributes of STEM education. Baltimore, MD: TIES.

O’Day, D. H., \& Liu, D. (2007). The value of animations in biology teaching: A study of long-term memory retention. CBE Life Sci Educ, 6(3), 217-223.

Pfeiffer, H. D., Ignatov, D. I., \& Poelmans, J. (2013). Conceptual structures for STEM research and education. 20th International Conference on Conceptual Structures, ICCS, Mumbai, India.

Pramuda, A., Mundilarto, Kuswanto, H., \& Hadiati, S. (2019). Effect of real-time physics organizer-based smartphone and indigenous technology to students' scientific literacy viewed from gender differences. International Journal of Instruction, 12(3), 253-270. https://doi.org/10.29333/iji.2019.12316a.

Prastowo, A. (2013). The creative guide makes innovative learning materials. Yogyakarta: Diva Press Rosdakarya.

Schunn, C. D. (2009). How kids learn engineering: The cognitive science perspective. The Bridge: Linking Engineering and Society, 39(3), 32-37.

Sohan, D. E., Waliczek, T. M., \& Briers, G. E. (2003). Knowledge, attitudes and perception regarding biotechnology among college students. J.Nat.Resour.Life.Sci.Educ, 31, 5-11.

Steiner, L., \& Morberg, A. (2006). Instructional strategies and student learning outcomes. An Article Presented at the Higher Education Conference, University of Lancaster 24-26/7.

Sudjana, N. (1990). Assessment of the results of the teaching and learning process. Bandung: Teen Rosdakarya.

Suprawoto, N. A. (2009). Develop learning materials with arrange module. Retrieved from http://www.scribe.com/doc/16554502/akso.

Supriyati, Y. (2011). Effectiveness of flash-based summative assessment using the anchor items on the learning of science. Paper presented at the New Perspective in Science Education.

Taylor, P. C. (2017). Why is STEAM curriculum perspective crucial to the $21^{\text {st }}$ century? Science education for diversity. Theory and Practice, 97-117.

Utomo, A. P., Novenda, I. L., Budiarso, A. S., \& Narulita, E. (2017). Development of learning material of biotechnology topic based on STEAM-LW approach for secondary school in coastal area. International Journal of Humanities Social Sciences and Education, 4(11), 121-127. 
Utomo, A. P., Prihatin, J., \& Pujiastuti. (2014). Pengembangan bahan ajar IPA Berbasis pendekatan sains teknologi masyarakat pada pokok bahasan limbah dan penanganannya kelas XI sekolah menengah kejuruan [Development of Science Learning Material Based on STS Approach in Waste and Handling Topic Grade XI Vocational School]. Pancaran Pendidikan, 3(4), 163-174.

Van den Akker. (1999). Principles and method of development research. In van den Akker, J., Branch, R. M., Gustafson, K., Nieveen, N., \& Plomp, T. (Eds.), Design approaches and tools in education and training (pp.1-14). Dordrecht: Kluwer Academic.

Veselinovska, S. S. (2015). Impact of the usage of animation in teaching cell biology on student achievement. In Researching paradigms of childhood and education (pp.56457). Opatija, Croatia: The Faculty of Teacher Education University of Zagreb.

Wahono, B., Rosalina, A. M., Utomo, A. P. \& Narulita, E. (2018). Developing STEM based student's book for grade xii biotechnology topics. Journal of Education and Learning 12(3), 450-456.

Yakman, G. (2008). STEAM education: An overview of creating a model of integrative education. In Pupils attitudes towards technology (pp.1-28). Netherland.

Yakman, G., \& Lee, H. (2012). Exploring the exemplary STEAM education in the U.S. as a practical educational framework for Korea. J Korea Assoc, Sci, Edu, 32(6), 10721086.

Zanin, M. K. B. (2015). Creating \& teaching with simple animation: Making biology instruction come alive. The American Biology Teacher, 77(6), 463-468. 